\title{
Student-Athlete Career Development through Community Service: A Retrospective Study
}

\author{
Jackson Zane Martin \\ University of Pittsburgh
}

\begin{abstract}
The purpose of this study was to examine, through a retrospective lens, the effects that collegiate community service has on the career development of student-athletes under the umbrella of functional motivation theory. To do so, researchers analyzed the career development of seven former Southeastern Conference (SEC) student-athletes who were awarded membership to the SEC Community Service team through both individual and team contributions. Although National Collegiate Athletic Association (NCAA) Division-I student-athletes face hindrances through time restraints, they also have resources designed to enhance academic and vocational development, such as the NCAA's Life Skills program (formerly CHAMPS, Challenging Athletes' Minds for Personal Success). Through phone interviews focused on reflective collegiate community service and career development, several themes emerged. For collegiate community service the most common themes were: service settings, current service, and time restraints. For career development, the major themes were: working with diverse groups, scholarship and admittance into graduate programs, and career choice/personal values. In analysis, the majority of the discovered themes align firmly with the National Association of College and Employer's (NACE) career readiness competencies. The results of this study implicate clear strategies for career development in the student-athlete population, but these strategies may be challenged by student-athletes' already crowded athletic, academic, and practice schedules and the lack of standardized measurements of student-athlete career development in NCAA institutions.
\end{abstract}

Keywords: career development, student-athlete development, community service, NCAA life skills, CHAMPS, NACE 


\section{Introduction}

While many factors contribute to post-collegiate employability, the relationship between academic success, extra-curricular involvement, and work experience in recent college graduates continues to shift as more employers look beyond the transcript and into other facets of a young professional's collegiate experience (Peter D. Hart Research Associates, 2006). Gone are the days when a bachelor's degree led directly to a job offer upon graduation. Instead, employers focus on well-rounded employees who combine academic success with practical experience, be it applied leadership, community service, or prior internships and job shadows (Peter D. Hart Research Associates, 2006). However, a particular subset of students is committed to obligations that inhibit commitment to most forms of long-term work during college. For this group, the often heralded and highly visible student-athletes, activities leading to well-roundedness and increased employability may cut into athletic obligations (possibly necessary to maintain scholarship) and academic requirements. Indeed, student-athletes may not have time to participate in extra-extracurricular activities beyond their sport and, therefore, are often unable take part in relevant professional development opportunities (Weisberg, 2011).

\section{Benefits of Student-Athlete Participation}

Participating in collegiate varsity athletics does come with benefits. Evidence shows that former collegiate student-athletes earn higher wages in the fields of business, military, and manual labor compared to general students (Henderson, Olbrecht, \& Polachek, 2006). Research, too, shows that intercollegiate athletics provides increased opportunities to engage in the surrounding community (Mixon \& Treviño, 2005), increases graduation and retention rates (2005), and allows student-athletes to exercise leadership, work ethic, teamwork, and time management (Pine, 2010).

In a summary of literature related to occupational careers among former athletes, Coakley (2015) noted that sport is connected to career success when it increases opportunities to complete academic degrees or develop job-related skills, increases support for growth and development not limited to athletic development and progression, and expands experiences, identities, and abilities unrelated to sports. All three of these items are facets of the National Collegiate Athletic Association's Life Skills program.

NCAA life skills/CHAMPS. The University of Florida at Gainesville in 1979 and Georgia Institute of Technology in 1981 were the first schools to implement personal and career counseling specific to student-athletes (Wittmer, Bostic, Phillips, \& Waters, 1981). Alongside academic monitoring, these athletic departments paved the way for student-athlete development by recognizing that student-athletes' personal issues are often manifested in poor grades (Wittmer et al., 1981). To accommodate student-athletes' rigorous schedules, the University of Florida also initiated a freshman-level academic course specifically for student-athletes, which dealt with personal growth and development and explored the following topics: interpersonal skills, effective leadership skills, career interest and planning, and time management.

With member schools increasing attention on the personal and professional development of student-athletes, The National Collegiate Athletic Association (NCAA) launched their 
CHAMPS (Challenging Athletes' Minds for Personal Success)/Life Skills program in 1994 to promote service and holistic development in student-athletes at the Division I, II, and III levels. The since retitled NCAA Life Skills program encourages athletic departments to develop widely applicable skills in the student-athlete population, including financial literacy, leadership training, stress management, and more. With this, athletic departments began hiring Life Skills administrators to take on these responsibilities and, in some cases, organize community service programs for student-athletes. Now, collegiate Life Skills professionals generally perform a trio of services for student-athletes, developing them personally and professionally while also coordinating and executing their community service.

\section{Career Development}

The career development of student-athletes is an area of research that has come into focus within the last few decades. While literature concerning collegiate community service highlights student-athletes' perceived benefits (McHugo, 2005), there is a dearth of information connecting the crucial functions of Life Skills professionals to the outcomes: student-athlete community service and career development. Typically, Division-I institutions adhering to the NCAA Life Skills mission provide student-athletes with avenues for professional networking, internship placement, career counseling, and opportunities for community service. However, while it is possible to gain professional experience even with athletic obligations, not every student-athlete can do so. In fact, there are pressures student-athletes face to perform (Pope \& Miller, 1996) that inhibit development of other crucial areas. Researchers ponder whether community service offers a low-commitment, low-pressure environment for student-athletes to gain personal and career development outside of athletics and academics.

While there are many instruments to measure the career maturity of student-athletes, there exists no determinant solution for the aforementioned barriers to student-athlete career development. Since a vast majority of collegiate Life Skills professionals are tasked with both enhancing the career development of student-athletes, as well as coordinating and executing community service initiatives, there are practical benefits for collegiate student-athletes, administrators, coaches, and other support staff to a study that answers the following question what effect does collegiate community service have on the career development of studentathletes?

\section{Functional Motivation Theory}

This study was conducted under the umbrella of functional motivation theory, which proposes that community service, as with any other social phenomena, is catalyzed by intrinsic or extrinsic motivating factors (Clary et al., 1998). In their theory, Clary et al. (1998) discussed six motivating factors for community service: (a) values, including altruistic and human concern for others; (b) understanding, or the chance to exercise knowledge, skills, and abilities that might otherwise go unpracticed; (c) opportunities to socialize with one's friends or to participate in an activity viewed favorably by others; (d) preparation or maintenance of career-relevant skills; (e) ego protection from guilt or other various personal problems; (f) mood enhancement. This theoretical framework was selected not only based on its focus on career-relevant skills, but also because it accounts for personal values, such as the altruistic and human concern for others. In 
relation to career development, the alignment between values and vocational choice have been identified as crucial in the career development process, specifically in the satisfaction and success of the professional (Brown, 2002; Sagiv, 2002; Sauermann, 2005; Sverko, 1989).

\section{Literature Review}

\section{Student-Athlete Community Service}

Community service is defined as the unpaid service that a person performs to benefit his or her community (Hiler, 2015). A study by McHugo (2005) gauged the benefits felt by studentathletes participating in community service activities, including social responsibility, attitude toward oneself, and future intentions to volunteer. However, student-athletes frequently volunteer in team outings. One particular piece of research utilized a case-study approach to examine the individual effects of community service participation on student-athletes and the impact of team dynamics as a result of involvement in community service (Jarvie \& Paule-Koba, 2012). Through a group interview with three male varsity basketball players at a Midwest NCAA Division-III institution, eight specific themes of coach support, enjoyment, helping hand, leadership, lessons learned, motivation, staying connected, and togetherness became evident after axial coding. However, this study is not holistically representative of the student-athlete population. With this in mind, it is important to recognize studies in which student-athlete participants in revenue-generating sport demonstrated significantly lower personal and career development results than non-revenue generating, and vice-versa (Beamon \& Bell, 2002, 2006; Wolniak, Pierson, \& Pascarella 2001).

Much research focuses on the motives and outcomes within collegiate community service and the benefits that arise (Beck \& Beck-Gernshiem, 2002; Maruallo \& Edwards, 2000). The previously cited studies describe volunteers who leverage volunteer experience and maximize individual and vocational benefits. Researchers have also peered into intentions to serve and civic responsibility in the student-athlete population (Gayles, Rockenbach, \& Davis, 2012). In a survey of 3,680 students across 46 institutions, researchers examined social activism, defined as the intent to reduce pain and suffering in the world, and charitable involvement, i.e., behavior that reduces pain and suffering (volunteering, donating money, participating in clothing or food drives, and helping friends with personal problems).

Hoffman, Kihl, and Browning (2015) theorized that student-athletes volunteer more regularly than non-student-athletes due to the NCAA's marketing campaigns focused on community service, such as their "Play it Forward" promotions (NCAA, 2014). Their prediction was correct - through the administration of the National Civic and Political Health Questionnaire (Lopez et al., 2006) to 467 college-aged students, researchers found that $79 \%$ of male studentathletes reported engaging in service within the past 12 months, whereas $62 \%$ of non-athlete males reported serving in the same time span. Likewise, $90 \%$ of female student-athletes reported volunteering in the past 12 months, while $87 \%$ of female non-athletes confirmed their participation.

A study by Chalk (2008) incorporating surveys and semi-structured interviews with student-athletes and athletic department administrators found six common factors in student- 
athletes' motivation to engage in community service, including social responsibility, intrinsic reward, and career experience. Moreover, interview data suggested that career experience and résumé building was important to student-athletes, and staff members confessed to "marketing" community service to student-athletes based on its résumé boosting capabilities.

Another recent study posed the discussion that institutional differences or similarities may contribute to servant leadership behaviors developed or exhibited by student-athletes through community service (Westfield, 2010). Via self-rated Servant Leadership Questionnaires, Westfield (2010) surveyed 133 student-athletes at two large Midwestern universities, one public and non-denominational and the other private and affiliated with the Catholic Church. Westfield discovered through multivariate analysis of covariance that student-athletes of the Catholic university scored significantly higher than student-athletes of the public university on altruistic calling, which is a desire to serve and willingness to put others' interest ahead of personal gain. Student-athletes at the Catholic university also scored statistically significantly higher in servant leadership subscales or persuasive mapping, i.e., the fostering of an environment that encourages creative problem-solving.

\section{Student-Athlete Career Development}

Research by Brown, Glastetter-Fender, and Shelton (2000) explored the relationship between career decision-making self-efficacy, career locus of control, athletic identity, and identity foreclosure among collegiate student-athletes. Results showed that hours of sport participation and practice, identity foreclosure, and career locus of control were inversely related to career decision-making self-efficacy. In summary, total immersion in collegiate sport without proper exploration of alternative roles resulted in lower self-efficacy for career decision-making tasks.

A qualitative study by Ackerman (2013) assessed the vocational identity of studentathletes and the lessons ingrained by participation in sport. Many participants stated that athletic involvement was a direct hindrance to career development. Lack of time outside of athletics, stress and mental exhaustion, and low grades due to lack of attendance were some negative influences apparent in the career development of these student-athletes. However, studentathletes also listed many valuable outcomes of athletic participation, such as transferable skills, scholarships, strong social relationships, and professional networking advantages.

Another study utilized retrospective interviews to compare the career maturity of collegiate student-athletes in their beginning and later years of eligibility (Lally \& Kerr, 2005). The interviews made evident the career maturity progression by these student-athletes, who had all but discarded their sport as career ambitions and instead focused on academics in their final years of eligibility. Likewise, Navarro (2012) examined the life experiences of 29 senior studentathletes to understand career aspirations for those nearing the transition to life after sport. The study found that student-athletes recognized the unlikelihood of a career competing in professional athletics, while nine of the 29 participants reported academic majors that didn't align with their career aspirations and were dictated by the time constraints of athletic obligations. 
A study by Linnemeyer and Brown (2010) compared student-athletes and non-studentathletes for developmental characteristics (e.g., career maturity and identity foreclosure) and additionally measured these same items in fine arts students. In the scope of career development, the average career maturity attitudes reported by the student-athletes was significantly lower than the mean for general students; their lower reported score than the fine arts students was not statistically significant, nor was the difference in the mean career maturity scores between the general students and fine arts students. This means that these two collegiate populations, studentathletes and fine arts students, may face similar hindrances and transitional challenges upon exit of their collegiate experience.

\section{Summary}

The previously discussed peer-reviewed research within the realms of student-athlete career development demonstrates a noticeable deficit for student-athlete career maturity within NCAA institutions, wherein the literature on student-athlete community service shows demonstrable effects on the participants involved. However, no research brings into focus said effects into student-athlete career development, exposing a void in useful and practical knowledge for practitioners in the student-athlete support services industry.

\section{Methods}

\section{Qualitative Research}

This study was designed to gain insight into the relationship between community service and career development of former student-athletes. The qualitative approach of this study, based in semi-structured interviews, allows sufficient data collection and flexibility, as the researcher had the opportunity to ask follow-up questions when appropriate. Furthermore, Fouad and ByarsWinston (2006) note that individuals' career development experiences differ with large environmental variables, and practitioners ought to understand clients' concerns through their cultural and environmental context to gain understanding of how those differential experiences affect their career development. As previously stated, this study was constructed under the umbrella of functional motivation theory.

\section{Retrospective Lens}

A retrospective lens enabled the researcher to investigate aspects of collegiate career development in those who have sufficiently developed their own careers. Retrospective studies are best used to explore or describe patterns of change and constructing histories about particular types of past events (De Vaus, 2006). However, one danger in using a retrospective study, particularly in a qualitative format, is faulty memory in the participant or population. While there is no guaranteed way to avoid such deficiencies of a retrospective study, interview questions were constructed under guidance of a faculty committee to avoid memory implantation (an acceptance of fictitious event as factual) or biased memory re-interpretation. 


\section{Population}

To ensure that participants were thoroughly engaged with community service as studentathletes, the researchers only solicited former Southeastern Conference (SEC) Community Service Team members for participation. The SEC is one of the only collegiate athletic conferences to recognize outstanding service efforts in post-season recognition, which it does for each of its 21 league-sponsored sports, choosing one athlete per the 14 member institutions. To qualify for the study, participants must have received their honor(s) between 1994 and 2013 to allow time to reflect on their collegiate experiences and develop their professional career. The researcher used purposive and convenience sampling in the recruitment and selection of participants. In purposive sampling, the goal is not to select participants at random but rather to select those who express interest and exclude those who do not (Patton, 2002). There was no incentive to participate. To gather the names of possible participants, the researcher e-mailed the SEC headquarters in Birmingham, Alabama, and each SEC institution's athletics' media relations departments. While the SEC headquarters provided substantial population information, their records were incomplete. Contacting the various media relation departments allowed the researcher to fill in necessary team-member and honoree gaps. The researcher contacted 14 participants through a mix of social media electronic messaging, and, when available, through personal e-mail and telephone. There were seven total respondents. The outreach utilizing personal contact reflects the convenience sampling, as the researcher contacted participants with personal relationships to increase the participation rate. Seven interviews were conducted representing three SEC Institutions and six varsity sports. Interviews ranged from 20 to 40 minutes in length with an average duration of 30 minutes. The interviews were conducted over the researcher's office phone and the audio was digitally recorded. To maintain confidentiality, legal names of participants were replaced by pseudonyms in the interview transcription. Year of award, professional title, and sport played remained in the transcript for analysis and coding.

\section{Interview Structure}

To investigate both collegiate community service and career development, the semistructured interview was segmented into two distinct portions, both of which featured a broad introductory question followed by three to four further questions. Questions were formulated by the researcher based on prior literature review and were critiqued by faculty members of the University of Tennessee, Knoxville. Participants signed an informed consent prior to the interview. Table 1 lists the introductory questions and follow-up questions for each portion of the interview. 
Table 1

Interview Questions

\begin{tabular}{ll}
\hline \multicolumn{1}{c}{ Community Service Questions } & \multicolumn{1}{c}{ Career Development Questions } \\
\hline $\begin{array}{l}\text { Tell me about your community service } \\
\text { experience while you were a student- } \\
\text { athlete? }\end{array}$ & $\begin{array}{l}\text { Tell me about how community service } \\
\text { has affected your career development? }\end{array}$ \\
$\begin{array}{ll}\text { How did you get involved with } \\
\text { community service? }\end{array}$ & $\begin{array}{l}\text { If pertinent, how did participating in } \\
\text { community service provide a sense of } \\
\text { possible careers? }\end{array}$ \\
$\begin{array}{ll}\text { In general, how did you decide which } \\
\text { activities to participate in? }\end{array}$ & $\begin{array}{l}\text { If applicable, how did participating in } \\
\text { community service provide you with a }\end{array}$ \\
$\begin{array}{l}\text { Who or what was influential in your } \\
\text { decision to participate? }\end{array}$ & $\begin{array}{l}\text { If applicable, how did participating in } \\
\text { community service help improve or build } \\
\text { transferable skills you use in your current }\end{array}$ \\
$\begin{array}{l}\text { How do you currently engage in } \\
\text { community service? }\end{array}$ & \begin{tabular}{l} 
occupation? \\
\hline
\end{tabular}
\end{tabular}

\section{Participants}

The participants represented a wide range of experiences in community service activities, as well as current occupation and collegiate sports. All participants exhausted their athletic eligibility per NCAA rules. For confidentiality purposes, gender-specific pseudonyms replace participants' names. Table 2 provides an overview of the participating interviewees. 
Table 2

Participant Information

\begin{tabular}{cccc}
\hline Name & Current Occupation & Sport Played & Award Year \\
\hline Henry & Sales Account Manager & Track \& Field & 2012 \\
Marie & Life Skills Coordinator & Basketball & 2010,2011 \\
Alexander & Youth Dive Coach; & Swim \& Dive & 2013 \\
& Graduate Student & & \\
Ashley & Nursing Student & Swim \& Dive & 2013 \\
Richard & Real Estate Broker & Baseball & 2013 \\
Grace & Medical School Student & Soccer & 2011 \\
Brenda & College Volleyball Coach & Volleyball & 2011 \\
\hline
\end{tabular}

\section{Recording, Transcription, and Coding}

The principal investigator digitally recorded the interviews and then transcribed and thematized from the text using open coding (Gallicano, 2013). Coding qualitative data means arranging it in a systematic order (Grbich, 2007). The purpose of analytical coding is "to search for patterns in data and for ideas that help explain why those patterns are there in the first place" (Bernard, 2006, p. 452). The researcher employed classification reasoning and intuitive senses to determine if data "looked alike" or "felt alike" when grouping and categorizing themes (Lincoln $\&$ Guba, 1985). These themes were intended to summarize or condense data. Data were coded manually during and after collection as an analytic tactic (Miles \& Huberman, 1994). Coding each interview immediately following transcription, rather than at the termination of data collection, helped the researcher observe similar themes within interviews and gauge possible data saturation.

\section{Findings \& Discussion}

Interviews and data analysis were intended to develop themes and observe the effect that community service had in former student-athletes' career development. During the interviews, several themes (represented in Figure 1) emerged in community service participation and career 
development in former student-athletes. An understanding of the participants' service gave the researcher further insight as to how similar experiences manifested in relation to professional development. Thus, both aspects of the interview were coded, and are represented in Figure 1. To denote the sequence of events in the interview, the dashed lines in Figure 1 denote a passage to the second stage of the interview, wherein the solid lines mark the semblance of themes following coding. For community service, the emergent themes were: service settings, current service, and time restraints. For career development, the emergent themes were: working with diverse groups, scholarship and admittance into graduate programs, and career choice/personal values. These themes are represented in Figure 1.

Figure 1. Emerging Themes

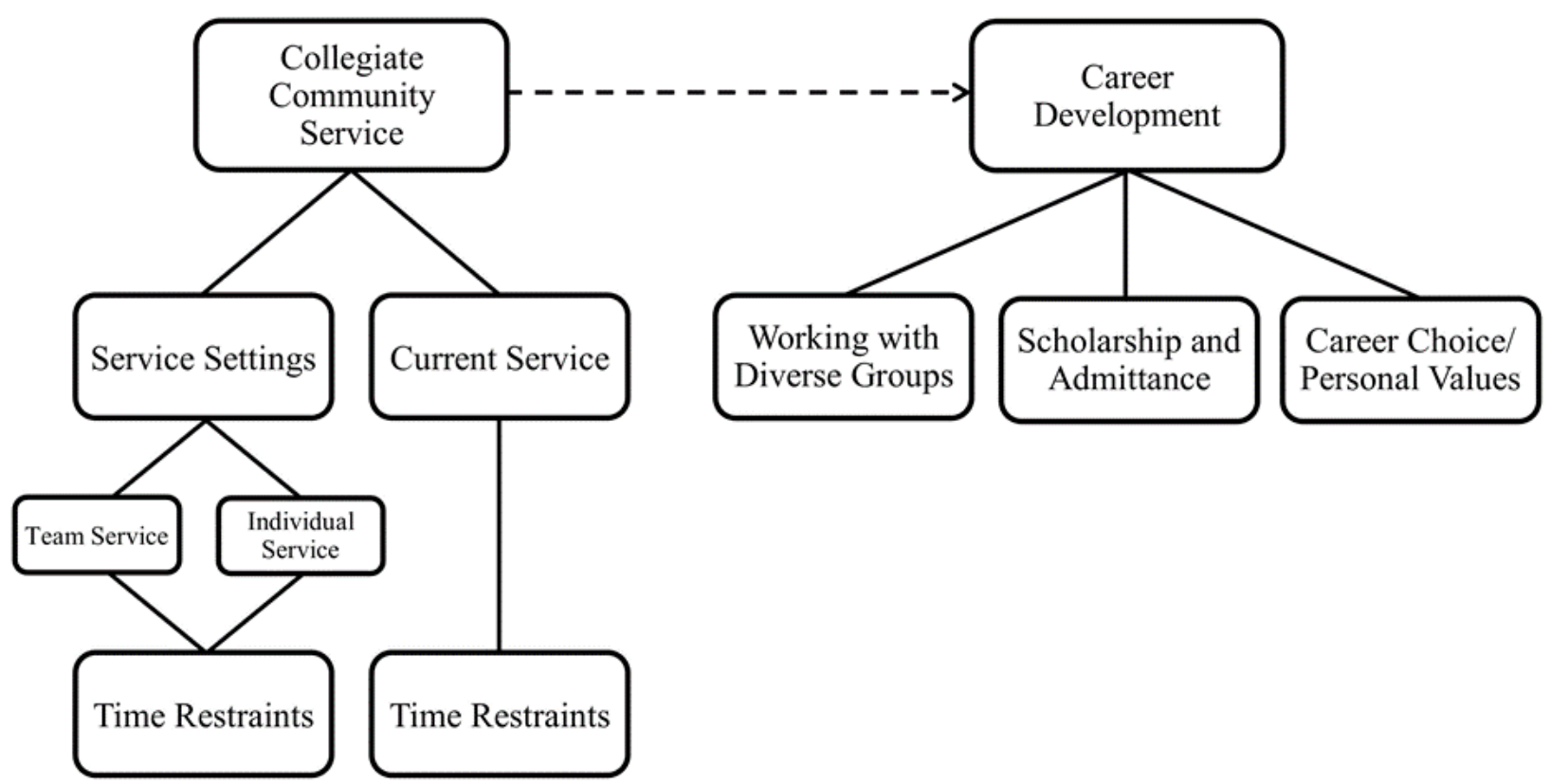

\section{Collegiate Community Service}

Service settings. The former student-athletes served with teammates, other studentathletes, or individually. All participants indicated that they served in a team or group setting, while four participants stated that they also served independently within athletic department supported functions, university initiatives, academic service learning, or otherwise.

Team service. All participants indicated that they engaged in community service outings with either their teammates or fellow student-athletes. This result echoes similar studies on student-athlete entrance and engagement in community service and volunteerism (Hoffman et al., 2015; Jarvie \& Paule-Koba, 2012; McHugo, 2005). For Grace and Henry, team service outings were a vehicle to bond with teammates. In particular, team outings helped Henry assimilate into the track and field team: "I kind of came in on my own... and so I figured [service] is a good way for me to get to know my teammates and kind of get out and meet people." 
It is possible that initially serving as a member of a larger team acts as a "gateway" into further volunteering. This is the case with Maria, a current Life Skills Coordinator who played collegiate basketball. Maria claimed:

My team, Coach . . . always did certain things, we did specific [service activities]... as a team. They always do the Alzheimer's walk, certain things like that were just kind of built in. And then, I asked to be on a listserv.

One participant serving on his own volition tried to incorporate teammates into his service project at a church near his university. For Alexander, a youth diving coach, it was important to spread the opportunity: "I tried to make it a . . diving thing. So I would bring my teammates with me, you know, invite them every Thursday I was going." Alexander's sentiments and group strategy are supported by research that suggests that one's social networks encourage volunteerism, either by direct request or by modeling volunteer behavior (HaskiLeventhal \& Cnaan, 2009).

Individual service. Four participants indicated that they completed collegiate service apart from their athletic departments or teams. It is clear that these former student-athletes had opportunities to serve within their teams, but some sought out their own opportunities based on prior instillation of servant values, as was the case with Alexander, who found his own volunteer outlet. Alexander admits that this endeavor was happenstance: "I fell into it. I was in a class, a sociology class early on in my career at [university] and we had to do a service learning component."

Brenda, a volleyball coach, felt similar academic influences in her independent service:

If I had someone at the school that influenced me it'd definitely be one of my, maybe two of my professors ... One was my sociology professor from my sophomore year... She was awesome, you walked into class and you can tell she just walked so many different parts of her life.

Brenda's experiences and academic influences in service are not only common with this pool of participants, but seem to be replicated in prior studies. Gage and Thapa (2012) found that teachers and families were responsible for introducing the majority of students to volunteerism at a major university in the southeast United States. Alexander noted the familial catalyst in serving:

For me, the story starts when I was younger, even before college. My family and my folks were really plugging me and my sister into different community service initiatives. We served at the Denver Rescue Mission when we were younger, and we rang the bell for the Salvation Army. I had a background and a foundation in serving, so when I got to school, it wasn't any different.

Research also indicates that community service in high school inspires adult service and political engagement (Hart, Donnelly, Youniss, \& Atkins, 2007). Ashley and Henry both 
referenced their Catholic high schools and religious upbringings as inciting their service. Ashley states: "I went to a Catholic high school. And I think that's really why... the culture is for me," while Henry cited specific service projects he was a part of: "We did this two-day retreat where we were homeless. We slept inside at the church, you know, we went to a soup kitchen and ate dinner there."

For one participant, it was not prior service that encouraged him to serve, but being the recipient of service and volunteerism. Richard, a former collegiate baseball player, grew up watching his father play professionally for a number of teams:

I always remember as a kid being in a big league clubhouse and the impact of a couple of the professional athletes, when they spent five to ten minutes with me. It literally changed my life.

Richard clearly understood the impact of a professional athlete and mentor on his youth, and this knowledge influenced his decision to continue serving in college and act as a positive role model for others. This socialization into the importance of serving as a role model is not uncommon in volunteering, especially in the workplace. Moreland and Levine (1982) found that employees who engaged in workplace volunteering had renewed energy and interest in volunteering as they transitioned into new supervisor roles that included mentoring others. It is possible that these role models' influence may affect other aspects of Millennial behavior, as was the case with Richard and his decision to engage in community service in college.

Time restraints and current service. While all participants engaged in campus and community service in college, many claimed that they most often participated in service that aligned with their restricted schedules. Their time was constrained by athletic and academic workloads, and oftentimes they could not pursue service opportunities of interest. Additionally, student-athletes are required to maintain academic standards to be eligible to compete and practice (NCAA, 2015). Four participants noted that they faced time restraints in pursuing current desired service opportunities. Henry cited a long commute and transition into a new position as the primary barriers to his service: "I'm actually working in a different town like 20 minutes away. I think, come the spring, depending on how things are going at work, I want to volunteer and coach, you know, middle school, club, do something like that." Grace commented on her relative decline in service from her time as a student-athlete to a full-time medical student, stating:

I wish I could get more involved. I've been saying that I need to. But I guess I just have put it off because so much time is spent studying ... I tell myself that I'm kind of being selfish now so that I can have a career that is spent serving others. Maybe it'll balance out in the end.

Former student-athletes' answers regarding community service shed light on commonalities in service setting and barriers, namely time demands of their post-athlete career. Unsurprisingly, in the transition into adulthood, the more months someone is engaged in full-time work, the less likely he or she is to participate in community service (Oesterle, Johnson, \& Mortimer, 2004). 


\section{Career Development}

Working with diverse groups. A significant theme arising in the interviews was the notion of working with diverse groups through community service. Oftentimes, the studentathletes' service was aimed towards underserved populations in their region, including youth, homeless citizens, the elderly, and hospital patients. While student-athletes may represent the most diverse population on college campuses (Loughran \& Etzel, 2005), this does not guarantee that participation within athletic departments is effective training for working with diverse or underserved populations. For Marie, working with underserved citizens didn't necessarily change her point of view, but gave her flexibility in working with those with differing viewpoints:

You don't have to see everything the way that this group or this organization... sees it, but you should be able to say, "Okay, I understand, that's cool. Either I agree or I don't agree, but we can still do this together."

Henry also commented on his experience with different groups and of the amount of tangible civility and inclusion skills gained in the process: "I also think that one of the greatest things [service] taught, I learned this a lot through Habitat for Humanity, was teaching you don't be quick to rush and judge anybody - see the best in people first." Complementing Henry's reflection, one study found that college students with prior experience in diverse groups scored higher on academic self-confidence, social agency, and critical thinking disposition than those who did not (Laird, 2005).

Organizational studies show that mutual respect for differences among employees can increase productivity in the workplace (Green, Lopez, Wysocki, \& Kepner, 2002). Diversity can also reduce litigious involvement, as well as increase creativity and organizational image (Esty, Griffin, \& Hirsch, 1995). For Marie, exposure to diverse populations and events allowed her to be selfless in the work environment, highlighting productive outings with her team members: "I don't think that [volunteering] makes you a more selfless person, but it brings that part out of you, and, that brings itself out, it lends to being a team player within a work environment."

From a managerial perspective, Brenda's experiences promoted empathy for different populations. She elaborated on this empathy by relating it to her profession as a college coach: "Us being able to develop some trust between each other makes my job coaching them so much easier because they know I understand them and understand where they're coming from." In today's workforce, it has been proven that empathy is positively related to job performance, especially for those in managerial positions (Gentry, Weber, \& Sadri, 2007).

Scholarship and admittance. For some, extensive service resulted in educational benefits. Marie, Henry, Grace, and Alexander all recalled how they leveraged their service and received either admittance into prestigious postgraduate programs or monetary benefits, such as scholarships via tuition waivers, graduate assistantships, or awards. In her application and interview for medical school, Grace utilized her experience to demonstrate her holistic interests and well-roundedness, writing in her personal statement about her collegiate soccer team's relationship with a child in the community, which included invitations to competitions and 
practices, and mentorship. Likewise, Alexander noted that his admission into a graduate program was affected by his collegiate community service: "[Service] definitely led me to the... program, and at the ... program, I've experienced just a ton of professional growth and personal growth... my network has grown exponentially." Additionally, Marie, who coordinates the Life Skills development of student-athletes at an SEC university, finds enticing skills in service for her student-athletes who seek full-time employment: "I will say that when employers call me and they're wanting student-athletes, they're wanting the ones that are involved... because it shows that they are committing to something and that they're able to manage their time."

For others, an acceptance letter was not the only byproduct of service, but also the scholarships and assistantships they received allowed them to attend graduate school for little to no cost. Henry, for example, served as a graduate assistant for Life Skills at an SEC university following his undergraduate career: "The most tangible thing [service brought] would obviously be... the award I got through the SEC, and then letters [of recommendation]... to grad school, the G.A. position, and [acceptance into] grad school." Even with further professional development in graduate school, many participants found that community service highlighted both their intended career path and personal and professional values.

Career choice/personal values. Four former student-athletes found that service helped identify personal values, morals, and guidelines that either inspired their intended career path or cemented their already decided trajectory. For Ashley, involvement in service brought selfdiscovery and confidence: "Sophomore year I did [service] and I finally grew into myself . . . I was a little more clear about what I wanted to do in my life." While her service undoubtedly improved her résumé, the transformation, gratitude, and maturity turned out to be more important for Ashley: "I realized that's it not just about putting it on your résumé, it's more about making a difference in someone else's life and how it can make a difference in your life as well."

Grace's intention to go to medical school was confirmed by her community service, particularly her visits to a local children's hospital:

I had it in the back of my mind that I wanted to go to medical school, but I wasn't totally sure. And then, when we would go to visit patients at hospitals, I remember always wishing that I could do more than just visit them, like actually help them out.

These sentiments are not unsurprising; similar results show that college students are able to explore their personal values (Rhoads, 1998) and leverage their employment opportunities (Maruallo \& Edwards, 2000) through community service.

\section{Limitations}

This study was limited by participants' institutions of study, as all seven participants competed at SEC institutions. These SEC institutions are located in a similar region in the country and adhere to SEC bylaws and codes of conduct. Given that the SEC encourages and rewards community service in student-athletes, the results of this study do not reflect the development of NCAA Division-I student-athletes in athletic conferences outside the SEC and participant pool. Furthermore, the researcher had previous relationships with three participants 
established through their work within collegiate student-athlete support services. Since the researcher's primary occupation was within an SEC athletic department, these previous relationships were utilized and beneficial in convenience sampling and the recruitment of participants. While it is difficult to determine if this affected participant responses, all interviews were conducted over-the-phone, minimizing the chance of interviewer effect (Schnite, 2001).

\section{Conclusions and Recommendations}

As stated previously, the purpose of this study was to gather information, in retrospect, from former student-athletes regarding their collegiate community service and its effect on their career development. Following participant interviews and coding, six clear themes emerged: service settings, current service, time restraints, working with diverse groups, scholarship and admittance into graduate programs, and career choice/personal values.

In relation to functional motivation theory (Clary et al., 1998) this research can certainly be applied to those volunteers who are extrinsically motivated, that is, they engage in an activity to obtain a separable outcome (Finkelstien, 2009). For example, student-athlete volunteers may be motivated to participate in community service given the tangible career development outcomes mentioned in this study. However, these career developments are not usually marketed as incentives within community service initiatives for college student-athletes. Martens and Lee (1998) stress an intervention model with student-athletes and the utilization of an institution's career services department. While Martens and Lee claim it is unlikely for freshmen studentathletes to visit career services of their own volition (1998), athletic departments can assist in this extrinsic motivation by promoting career services' resources. With the results of this study, one can observe that community service offers tangible benefits to student-athletes' career development, particularly validated by recent research through the National Association of Colleges and Employers.

\section{Career Readiness}

To guide partner institutions in the career development of college students, the National Association of College and Employers (NACE) surveyed hundreds of representatives from organizations that hire through university recruiting (NACE, 2014). These career readiness competencies are broad pre-requisites for a successful transition into the workplace for college graduates, with transference over various industries. These competencies include critical thinking/problem solving, oral/written communications, teamwork/collaboration, digital technology, leadership, professionalism/work ethic, career management, and global/intercultural fluency (NACE, 2017). Four of the discovered themes align with the career competencies as defined in Table 3. 
Table 3

Corresponding NACE Career Competencies

\begin{tabular}{|c|c|c|}
\hline Discovered Theme & $\begin{array}{l}\text { NACE Career } \\
\text { Competency }\end{array}$ & NACE Competency Definition \\
\hline Team Service & Teamwork/Collaboration & $\begin{array}{l}\text { "... able to work within a team structure, } \\
\text { and can negotiate and manage conflict." }\end{array}$ \\
\hline Individual Service & $\begin{array}{l}\text { Professionalism/Work } \\
\text { Ethic }\end{array}$ & $\begin{array}{c}\text { "... able to demonstrate personal } \\
\text { accountability and effective work } \\
\text { habits." }\end{array}$ \\
\hline $\begin{array}{l}\text { Working with Diverse } \\
\text { Groups }\end{array}$ & $\begin{array}{l}\text { Global/Intercultural } \\
\text { Fluency }\end{array}$ & $\begin{array}{c}\text { "... able to interact respectfully with all } \\
\text { people and understand individuals' } \\
\text { differences." }\end{array}$ \\
\hline $\begin{array}{l}\text { Career Choice/Personal } \\
\text { Values }\end{array}$ & Career Management & $\begin{array}{c}\text { “.. able to identify and articulate one's } \\
\text { skills, strengths, knowledge, and } \\
\text { experiences relevant to the position } \\
\text { desired and career goals." }\end{array}$ \\
\hline
\end{tabular}

The data and experiences of the participants demonstrate the competencies listed and corresponding definitions. The NACE career readiness themes consider surveyed employer preferences, as opposed to strictly the perspective of collegiate career development professionals. This means that the career readiness competencies were defined by those in position to employ persons, including former collegiate student-athletes, into careers (NACE, 2014). While NACE establishes specific competencies that college students ought to gain in order to secure employment, the NCAA Life Skills commitment to "total development of student-athletes" does not take into account the lens of prospective employers (NCAA, 2016).

\section{Implications and Practical Applications}

As stated before, functional motivation theory (Clary et al., 1998) supposes that participants are motivated to perform community service by six possible outcomes, one being the preparation or maintenance of career-relevant skills. Earlier studies reinforce this theory, in particular that certain student-athletes are motivated by employability in community service participation (Holdsworth, 2010), but may be unaware of the professional and career developmental processes associated with vocational success. As mentioned earlier, no determinant solution has yet been offered for student-athletes' demonstrated career immaturity, but this study asserts clear, career-ready skills, as defined by NACE, which former studentathletes gained through community service. 
In practice, collegiate athletic departments could implement this observation in their Life Skills programming or at least offer some education involving this relationship. For instance, an athletic department could offer a workshop on the professional benefits of leveraging community service experiences to student-athletes engaged in community and civil service. Furthermore, student-athletes and administrators may find it beneficial to implement service-learning opportunities for student-athletes in order to promote a holistic student-athlete career development process.

In fact, many university career services departments are changing their branding to reflect such processes, viewing their focuses not as job placement, but as students' ongoing professional development (Canning, 2014). Based on this study, athletic departments may find it best practice to encourage community service as it catalyzes professional exploration, a crucial step in the career development process (Super, 1980).

For other athletic department members, this study may be useful in affirming the benefit of student-athletes' community service participation, or general holistic programming, to coaches and administrators of collegiate athletic departments. Implementing service based on studentathletes' schedules and interests is not a novel concept, but this study supports the practice as worthwhile for personal and professional benefits, especially since research shows community service is predictive of leadership and other positive interpersonal behaviors (Vogelsang \& Astin, 2000).

These hypothetical practices are not without their challenges. Perhaps the biggest hurdle of implementing service-based career development programming is coordinating around studentathletes practice, competition, and academic schedules. Based on a 2015 survey of NCAA Division-I student-athletes, student-athletes reported spending between 4.4 and 8.5 hours on their sport during a typical day of competition (NCAA, 2015). Additionally, two-thirds of surveyed Division-I student-athletes said they spend as much or more time on athletics during the offseason as during the competitive season (NCAA, 2015). Available time for service-based career development programming is extremely limited. One option to engage student-athletes would be to engage coaching staffs with extrinsic motivation by connecting job placement metrics to a coach's annual performance review. As much as the NCAA mandates academic standards for student-athletes and athletic teams, it may be beneficial for student-athletes' holistic development for the governing body, or institutions, to establish standards for career development within the student-athlete population. As mentioned previously, the NCAA Life Skills curriculum and mission is not coordinated with NACE's employment-based competencies (NCAA, 2016). Alignment with NACE would help the NCAA establish standard measuring instruments for job placement and student-athlete career development that institutions can adhere to. While this study asserts that certain competencies can be gained through rigorous community service, the majority of NCAA student-athletes do not, and will not garner the amount of service as participants in this study due to time demands associated with sport and academics.

In the near future, it is unlikely that time demands of student-athletes will diminish or lower. However, there may be an alternative to providing developmental experiences for the student-athlete population. Some athletic departments are looking to help student-athletes develop following the exhaustion of their athletic eligibility, through post-eligibility 
programming. Specifically, the University of Nebraska-Lincoln Post-Eligibility Opportunities program provides letter-winning alumni a one-semester scholarship, valued up to $\$ 7,500$, to apply toward an internship, study abroad experience or graduate school at the University of Nebraska-Lincoln or the University of Nebraska Medical Center (The University of NebraskaLincoln, 2017). While some universities offer graduate scholarship or fellowship to former student-athletes, University of Nebraska-Lincoln's program is unique in offering scholarship for former student-athletes to pursue developmental experiences outside the traditional college classroom. This practice and style of post-eligibility programming may be effective in addressing the voids of student-athlete development, as post-eligibility programming can assist studentathletes' personal and professional development while avoiding athletic scheduling conflicts and time demands associated with still-eligible NCAA student-athletes.

\section{Future Research}

A subsequent result of this research may be further study on the subject. Additional research could offer quantitative results to the connection, such as post-graduation employment rates and collegiate community service rates in student-athletes. Further research could also investigate collegiate community service participation through the lens of prospective employers, coaches, and administrators. Future researchers should also consider other qualitative data collection approaches to the topic, such as focus groups and case studies. 


\section{References}

Ackerman, C. (2013). Exploration of factors relation to the development of vocational identity in collegiate student-athletes. (Unpublished doctoral dissertation). University of Kansas, Lawrence, KS. Retrieved from http://kuscholarworks.ku.edu/bitstream/handle/1808/10125/Ackerman_ku_0099D_12048 _DATA_1.pdf?sequence $=1 \&$ isAllowed $=\mathrm{y}$

Beamon, K., \& Bell, P. (2002). Going pro: The differential effects of high aspirations for a professional sports career on African-American student-athletes and White studentathletes. Race and Society, 5, 179-191.

Beamon, K., \& Bell, P. (2006). Academics versus athletics: An examination of the effects of background and socialization on African-American male student-athletes. The Social Science Journal, 43, 393-403.

Beck, U. \& Beck-Gernsheim, E. (2002). Individualisation: Institutionalized individualism and its social and political consequences. London: Sage

Bernard, H. R. (2006). Research methods in anthropology: Qualitative and quantitative approaches. Lanham, MD: AltaMira Press

Brown, C., Glastetter-Fender, C., \& Shelton, M. (2000). Psychosocial identity and career control in college student-athletes. Journal of Vocational Behavior. 56(1), 53-62.

Brown, D. (2002). The role of work and cultural values in occupational choice, satisfaction, and success: A theoretical statement. Journal of Counseling \& Development, 80(1), 48-56.

Byars-Winston, A. M., Fouad, N. A. (2006). Metacognition and multicultural competence: Expanding the culturally appropriate career counseling model. Career Development Quarterly, 54, 187-201.

Canning, J. (2014). Times are a changin' for college career services. Learning Advisor. Retrieved from http://blog.studentadvisor.com/times-changin-college-career-services/

Chalk, P. (2008). Motives and values associated with participation in intercollegiate student-athlete community service: Implications for athletics department leadership (Unpublished doctoral dissertation). University of Arizona, Tucson, Arizona.

Clary, E. G., Snyder, M., Ridge, R. D., Copeland, J., Stukas, A. A., Miene, P., \& Haugen, J. (1998). Understanding and assessing the motivations of volunteers: A functional approach. Journal of Personality and Social Psychology, 74(6), 1516-1530.

Coakley, J. (2015). Sports in society: Issues and controversies. New York, NY: McGraw-Hill Education.

De Vaus, D. (2006). Retrospective study. The SAGE Dictionary of Social Research 
Methods. Retrieved from

http://srmo.sagepub.com/view/the-sage-dictionary-of-social-research-methods/n181.xml

Esty, K., Griffin, R., \& Hirsh, M. S. (1995). The dynamics of diversity.

A managers guide to solving problems and turning diversity into a competitive advantage (pp. 1-12). Avon, MA: Adams Media Corporation.

Finkelstien, M. A. (2009). Intrinsic vs. extrinsic motivational orientations and the volunteer process. Personality and Individual Differences, 46(5-6), 653-658.

Fouad, N., \& Byars-Winston, A. (2005). Cultural context of career choice: Meta analysis of race differences. Career Development Quarterly, 53, 223-233.

Gage, R., \& Thapa, B. (2012). Volunteer motivations and constraints among college students. Nonprofit and Voluntary Sector Quarterly, 41(3), 405-430.

Gallicano, T. (2013). An example of how to perform open coding, axial coding, and selective coding. The PR Post. Retrieved from http://www.sciencedirect.com/science/article/pii/S014019718471030X

Gayles, J. G., Rockenbach, A. B., \& Davis, H. A. (2012). Civic responsibility and the student athlete: Validating a new conceptual model. The Journal of Higher Education, $83(4), 535-557$.

Gentry, W. A., Weber, T. J., \& Sadri, G. (2007). Empathy in the workplace: A tool for effective leadership, presented at Society of Industrial Organizational Psychology Conference, 2007. New York, NY: Center for Creative Leadership.

Grbich, C. (2007). Qualitative data analysis: An introduction. London: SAGE Publications Ltd.

Green, K. A., Lopez, M., Wysocki, A., \& Kepner, K. (2002). Diversity in the workplace: Benefits, challenges the required managerial tools. IFAS Extension.

Hart, D., Donnelly, T. M., Youniss, J., \& Atkins, R. (2007). High school community service as a predictor of adult voting and volunteering. American Educational Research Journal, 44(1), 197-219.

Haski-Leventhal, D., \& Cnaan, R.A. (2009). Group processes and volunteering: Using groups to enhance volunteerism. Administration in Social Work, 33(1), 61-80.

Henderson, D. J., Olbrecht, A., \& Polachek, S. (2006). Do former college athletes earn more at work? A nonparametric assessment. The Journal of Human Resources, 41(3), 558-577.

Hiler, S. (2015). Community Service: A definition. [class handout]. Trinity Valley School, Fort 
Worth, Texas. Retrieved from

https://www.trinityvalleyschool.org/uploaded/community_service/brochure_and_contract .pdf

Hoffman, J., Kihl, L., \& Browning, A. (2015). Civic engagement and activism: Do college students and college athletes differ? Journal of College and Character, 16(2), 75-89.

Holdsworth, C. (2010). Why volunteer? Understanding motivations for student volunteering. British Journal of Educational Studies, 58(4), 421-437.

Jarvie, B. D., \& Paule-Koba, A. L. (2012). The perceptions and effects of community service participation among intercollegiate men's basketball players. Journal of Issues in Intercollegiate Athletics, 5, 283-300.

King, E. B, Dawson, J. F., Kravitz, D. A., \& Gulick, L. M. (2012). A multilevel study of the relationships between diversity training, ethnic discrimination, and satisfaction in organizations. Journal of Organizational Behavior, 33(1), 5-20.

Laird, T. F. (2005). College students' experiences with diversity and their effects on academic self-confidence, social agency, and disposition toward critical thinking. Research in Higher Education, 46(4), 365-387.

Lally, P. S. \& Kerr, G. A., (2005). The career planning, athletic identity, and student role identity of intercollegiate student athletes. Research Quarterly for Exercise and Sport, 76(3), 275-285.

Lincoln, Y. S. \& Guba, E. G. (1985). Naturalistic inquiry. Newbury Park, CA: Sage Publications.

Linnenmeyer, R. M., \& Brown, C. (2010). Career maturity and foreclosure in student athletes, fine arts students, and general college students. Journal of Career Development 37(3), 616-634.

Lopez, M. H., Levine, P., Both, D. Kiesa, A., Kirby, E., \& Marcelo, K. (2006). The 2006 civic and political health of the nation: A detailed look at how youth participate in politics and communities. College Park, MD: Center for Information and Research on Civic Learning and Engagement (CIRCLE). Retrieved from https://civicyouth.org/PopUps/2006_CPHS_Report_update.pdf

Loughran, M. J., \& Etzel, E. F. (2005). Ethical practice in a diverse world: The challenges of working with differences in the psychological treatment of college student-athletes. Athletic Insight: The Online Journal of Sport Psychology, 10(4). Retrieved from http://www.athleticinsight.com/Vol10Iss4/Ethical.htm

Martens, M.P., \& Lee, F.K. (1998). Promoting life-career development in the student 
athlete: How can career centers help? Journal of Career Development, (25)2. 123-134.

Marullo, S. \& Edwards, B. (2000). From charity to justice: The potential of universitycommunity collaboration for social change. American Behavioral Scientist, 43(5), 895-912.

McHugo, M. P. (2005). The benefits felt by division I-A student-athletes from participation in community service activities: A case study. Electronic Theses, Treatises and Dissertations. Retrieved from http://diginole.lib.fsu.edu/cgi/viewcontent.cgi? article=3678\&context=etd

Miles, M. B. \& Huberman, A. M. (1994). Qualitative data analysis (2nd ed.). Thousand Oaks, CA: Sage Publications.

Mixon, F. G., \& Treviño, L. J. (2005). From kickoff to commencement: The positive role of intercollegiate athletics in higher education. Economics of Education Review, 24, $97-102$.

Moreland, R. L. \& Levine, J. M. (1982). Socialization in small groups: Temporal changes in individual-group relations. Advances in Experimental Social Psychology, 15, 137-192.

National Association of Colleges and Employers (2014). Career readiness defined. Retrieved from http://www.naceweb.org/career-readiness/competencies/career-readiness-defined/

National Association of Colleges and Employers. (2017). Career readiness for the new college graduate: A definition and competencies. Retrieved from http://www.naceweb.org/uploadedfiles/pages/knowledge/articles/career-readiness-factsheet.pdf

National Collegiate Athletic Association. (2014). Playing it Forward: Commitment to Service Among Student-Athletes. [Flyer]. Retrieved from https://www.ncaa.org/sites/default/files/Civic\%20Engagement\%20Among\%20SAs_pic_ts p_sc2_lfb_clean_tsp2_lfb2_sc4.pdf

National Collegiate Athletic Association. (2015). Division I Manual. Retrieved from https://www.ncaapublications.com/p-4388-2015-2016-ncaa-division-i-manual-augustversion-available-august-2015.aspx

National Collegiate Athletic Association. (2015). Time management: What Division I studentathletes should expect [PDF File]. Retrieved from https://www.ncaa.org/sites/default/files/StudentAthleteTimeManagement.pdf

National Collegiate Athletic Association (2016). Life Skills. Retrieved from http://www.ncaa.org/about/resources/leadership-development/life-skills 
Navarro, K. M. (2012). Toward an understanding of career construction in the $21^{\text {st }}$ century: Phenomenological study of the life experiences of graduating student-athletes at a large highly-selective midwestern university. (Unpublished Doctoral Dissertation). University of Wisconsin-Madison. Retrieved from https://search.proquest.com/docview/1017869893

Oesterle, S., Johnson, M. K., \& Mortimer, J. T. (2004). Volunteerism during the transition to adulthood: A life course perspective. Social Forces, 82(3), 1123-1149.

Patton, M. Q. (2002). Qualitative research and evaluation methods. Thousand Oaks, CA: Sage Publications.

Peter D. Hart Research Associates, Inc. (2006). How should colleges prepare students to succeed in today's global economy? Retrieved from http://www.aacu.org/sites/default/files/files/LEAP/2007_full_report_leap.pdf

Pine, N. (2010). The role of athletics in the academy: An alternative approach to financial investment. Journal of Sport and Social Issues, 34(4), 475-480.

Pope, M. L., \& Miller, M.T. (1996). A Review of Literature Related to Service for College Student-Athletes. Retrieved from https://www.researchgate.net/publication/234606479_A_Review_of_Literature_Related_ to_Service_for_College_Student-Athletes

Porter, J. (2015). Diversity training myths your company needs to drop now. Fast Company. Retrieved from http://www.fastcompany.com/3042932/strong-femalelead/diversity-training-myths-your-company-needs-to-drop-now

Sagiv, L. (2002). Vocational interests and basic values. Journal of Career Assessment, 10(2), 233-257.

Sauermann, H. (2005). Vocational choice: A decision making perspective. Journal of Vocational Behavior, 66(2), 273-303.

Schnite, K. E. (2001). The impact of interviewer characteristics on respondent characteristics that influence item non-response. Paper presented at the Annual Meeting of the American Statistical Association. Retrieved from http://www.amstat.org/sections/srms/proceedings/y2001/Proceed/00294.pdf

Super, D. E. (1980). A life-span, life-space approach to career development. Journal of Vocational Behavior, 16, 282-298.

Sverko, B. (1989). Origin of individual differences in importance attached to work: A model and a contribution to its evaluation. Journal of Vocational Behavior, 34, 28-39.

The University of Nebraska-Lincoln (2017). Post-Eligibility Opportunities Overview. Retrieved From 
http://www.huskers.com/ViewArticle.dbml?DB_OEM_ID=100\&ATCLID=210245693

Vogelsang, L. J., \& Astin, A. W. (2000). Comparing the effects of community service and service-learning. Michigan Journal of Community Service Learning, 7(1), 26-34.

Weisberg, S. (2011, January 15). NCAA survey delves into practice time, coaches' trust. USA Today. Retrieved from http://usatoday30.usatoday.com/sports/college/2011-01-14-ncaa-survey_N.htm

Westfield, D. (2010). The effects of participation in community service through intercollegiate athletics on servant leadership behaviors. (Unpublished doctoral dissertation). University of Nebraska, Lincoln. Retrieved from http://digitalcommons.unl.edu/cgi/viewcontent.cgi?article=1011\&amp;context=aglecdiss

Wittmer, J., Bostic, D., Phillips, T. D., \& Waters, W. (1981). The personal, academic, and career problems of college student athletes: Some possible answers. Personnel and Guidance Journal, 60(1), 52-55.

Wolniak, G. C., Pierson, C. T., \& Pascarella, E. T. (2001). Effects of intercollegiate athletics participation on male orientations toward learning. Journal of College Student Development, 42(6), 604-624. 